\title{
THE VALUE OF GRASS SILAGE FOR FEEDING DAIRY COWS IN PUERTO RICO
}

\section{J. I. Cabrera and L. Rivera-Brenes ${ }^{1}$ \\ INTRODUCTION}

For a great many years the advantages of preserving green forage crops for winter and drought seasons has been recognized. As early as 1786 $(1)^{2}$ history records that the Italians preserved green crops for their animals by storing them in pits under the ground. The French and English are known to have stored green crops a century and a half ago. In the United States, credit is given to Fred L. Hatch for building the first silo on his farm, in 1873. In Puerto Rico, D. W. May (2) erected the first silo at the Federal Experiment Station at Mayagüez. For some time after farmers were slow to follow his example and it is only in comparatively recent years that silos have been in use throughout the southern and northern coasts of the Island.

\section{REVIEW OF LITERATURE}

The literature on the nutritive value of silage and its preparation is very extensive and widely known. May (2) failed in preparing Para grass (Panicum purpurascens), Guinea grass (Panicum maximum), and cane tops (Sacharum officinarum) silage. The cane-top silage was sour probably because of its condition when put into the silo. Rivera Brenes (3) et al., published the first work done at this Station on the preparation of silage. They laid the foundations for the work reported here. It was concluded that Para grass, Merker grass (Pennisetum purpurascens va. Merkerii), and cane tops made a rather good silage. Better quality silage was obtained when using Merker grass than when using either of the other two roughages.

\section{EXPERIMENTAL PROCEDURE}

Feeding trials were conducted to determine the value of Merker grass at two stages of maturity, Para grass with 5 or 10 percent of molasses, and immature whole sugarcane as silage. These trials covered a period of 3 years starting January 1947. Usually these silages were compared with Merker grass fed as soilage.

Silage was prepared according to the availability of the forages and other

${ }^{1}$ Assistant Animal Husbandman and Associate Animal Husbandman, Head of the Animal Husbandry Department, respectively, Agricultural Experiment Station, University of Puerto Rico, Río Piedras, P. R.

2 Numbers in parentheses refer to Literature Cited, p. 73. 
facilities. Enough silage was made at a time to run a feeding trial. Molasses was generally used as a preservative.

The animals used came from our experimental herd and were mostly grades. These cows were grouped taking in consideration their production and stage of lactation.

The direct and double-reversal methods of experimentation were used in comparing the different roughages studied.

Prefeeding periods of from 5 to 7 days were followed by experimental periods of 21 to 28 days. During the prefeeding period the cows were weighed and the concentrate rations adjusted. The concentrate ration

TABLE 1.-Proximate analyses of the various roughages compared in feeding experiments with dairy cows

\begin{tabular}{|c|c|c|c|c|c|c|c|}
\hline Roughage studied & Samples & $\underset{\text { Dry }}{\text { Drter }}$ & Ash & Protein & Fat & Fiber & N. F.E. \\
\hline & Number & Percent & Percent & Percent & Percent & Percent & Percent \\
\hline Immature Merker grass. & 36 & 18.05 & 9.34 & 6.08 & 1.45 & 35.84 & 47.28 \\
\hline Mature Merker grass.... & 19 & 26.94 & 6.80 & 5.93 & 1.97 & 33.80 & 50.68 \\
\hline Mature Para grass. & 5 & 30.60 & 6.03 & 7.59 & 2.09 & 31.42 & 52.87 \\
\hline $\begin{array}{c}\text { Immature Merker grass } \\
\text { silage................... }\end{array}$ & 11 & 20.10 & 12.32 & 5.85 & 2.04 & 29.17 & 50.61 \\
\hline Mature Merker grass silage... & 20 & 27.11 & 12.28 & 6.25 & 2.29 & 31.22 & 47.48 \\
\hline $\begin{array}{c}\text { Para grass silage, } 5 \text {-percent } \\
\text { molasses ........................ }\end{array}$ & 5 & 21.71 & 15.54 & 7.08 & 1.31 & 30.41 & 45.64 \\
\hline $\begin{array}{l}\text { Para grass silage, } 10 \text {-percent } \\
\text { molasses } \ldots \ldots \ldots \ldots \ldots \ldots \ldots\end{array}$ & 5 & 29.53 & 18.24 & 8.42 & 1.39 & 24.60 & 47.38 \\
\hline Merker-kudzu grass........ & 6 & 20.21 & 8.80 & 6.35 & 1.58 & 38.27 & 45.00 \\
\hline Merker-kudzu silage... & 6 & 24.82 & 9.37 & 4.71 & 1.39 & 35.60 & 48.86 \\
\hline Immature sugarcane. . & 3 & 21.54 & 8.04 & 4.31 & 1.42 & 31.90 & 54.32 \\
\hline Immature sugarcane silage... & 20 & 20.54 & 10.73 & 5.00 & 1.44 & 33.63 & 49.19 \\
\hline
\end{tabular}

was left unchanged to render constant the quantity of nutrients derived from it throughout the entire experimental period. This ration was calculated on a production period of 10 days prior to the beginning of the trial. Daily concentrate and roughage consumption, as well as milk-production records, were kept throughout. The roughage was fed ad libitum and the concentrate at a ratio of 1 pound per $2 \frac{1}{2}$ pounds of milk produced. All animals used were weighed at the beginning and at the end of each experimental period.

The following feeding trials were performed: Mature Merker grass silage vs. Para grass soilage; immature Merker grass silage vs. mature Merker grass silage, 34 days difference in age; immature Merker grass silage vs. mature Merker grass silage vs. mature Merker grass; Para grass silage plus 5 or 10 percent of molasses vs. mature Merker grass soilage; mature Merker grass silage vs. immature Merker grass soilage; mature 
Merker-kudzu grass silage vs. mature Merker grass; and immature sugarcane vs. mature Merker grass. Table 1 shows the proximate analyses of the roughages compared.

TABLE 2.-Milk production of cows on Para grass and on Merker grass silage ${ }^{1}$

\begin{tabular}{|c|c|c|c|}
\hline Cow & Base period & Test period & Difference \\
\hline \multicolumn{4}{|c|}{ Group 1: Cows receiving Para grass (Malojillo) } \\
\hline & Pounds & Pounds & Pounds \\
\hline Jewel. . & 27.0 & 25.5 & 1.5 \\
\hline Walker Jr.................. & 29.2 & 27.2 & 2.0 \\
\hline Pontiac.............. & 26.0 & 24.2 & 1.8 \\
\hline Princesa............. & 24.2 & 22.7 & 1.5 \\
\hline Rosalinda............. & 11.6 & 8.5 & 3.1 \\
\hline Queen......... & 10.8 & 11.1 & -.3 \\
\hline Denia....................... & 16.9 & 15.8 & 1.1 \\
\hline 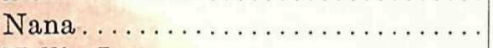 & 13.7 & 11.6 & 2.1 \\
\hline Nellie Jr....... & 13.7 & 12.1 & 1.6 \\
\hline Enanita....... & 11.5 & 9.0 & 2.5 \\
\hline Redonda....... & 17.7 & 13.9 & 3.8 \\
\hline 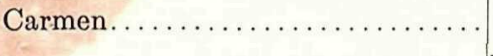 & 10.2 & 8.2 & 2.0 \\
\hline Average..... & 17.71 & 15.81 & 1.90 \\
\hline
\end{tabular}

Group 2: Cows receiving Merker silage

\begin{tabular}{|c|c|c|c|}
\hline Lupe... . & 34.2 & 32.2 & 2.0 \\
\hline Luisa $32 \ldots \ldots$. & 27.4 & 26.6 & .8 \\
\hline Nellie...................... & 25.8 & 24.5 & 1.3 \\
\hline 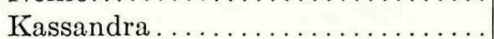 & 20.6 & 19.5 & 1.1 \\
\hline$\ldots \ldots \ldots \ldots \ldots$ & 15.9 & 14.7 & 1.2 \\
\hline Canaria......... & 11.9 & 12.2 & -.3 \\
\hline Angelina........ & 17.3 & 15.6 & 1.7 \\
\hline Berta............ & 13.4 & 13.9 & -.5 \\
\hline Mulata.......... & 12.4 & 13.0 & -.6 \\
\hline Nena..$\ldots \ldots \ldots \ldots \ldots \ldots \ldots \ldots$ & 13.6 & 13.3 & .3 \\
\hline Guinea........................ & 13.3 & 14.4 & -1.1 \\
\hline Yolanda..... & 12.8 & 11.1 & 1.7 \\
\hline Average...$\ldots \ldots \ldots \ldots \ldots$. & 18.22 & 17.58 & .64 \\
\hline
\end{tabular}

${ }^{1}$ Difference between groups in decline of production, $1.90-0.64=1.26 \mathrm{lbs}$. of milk per day.

\section{Mature Merker Grass Silage Vs. Mature Para Grass Soilage}

Two groups of 12 cows each were used in this feeding trial. All of them were on Para grass soilage for about 4 weeks prior to the start of the com- 
parison. The silage group had a prefeeding period of 6 days. Table 2 contains the milk-production data and table 3 the data on forage consumption for the test period.

TABLE 3.-Forage consumption of cows on Para grass and on Merker silage during test period

\begin{tabular}{|c|c|c|}
\hline Cow & Average per day & $\begin{array}{l}\text { Per } 100 \text { lbs. of body } \\
\text { weight }\end{array}$ \\
\hline \multicolumn{3}{|c|}{ Group 1: Cows receiving Para grass } \\
\hline & Pounds & Pounds \\
\hline$\ldots \ldots \ldots \ldots \ldots \ldots \ldots$ & 89.0 & 6.89 \\
\hline 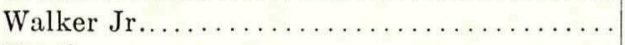 & 72.3 & 7.37 \\
\hline 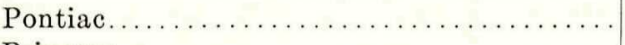 & 86.6 & 7.59 \\
\hline 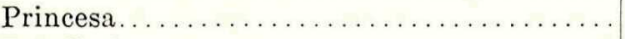 & 82.8 & 7.39 \\
\hline 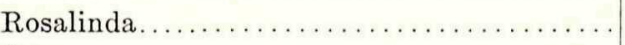 & 55.5 & 6.09 \\
\hline 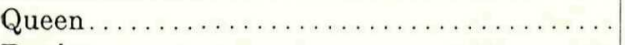 & 93.9 & 6.61 \\
\hline 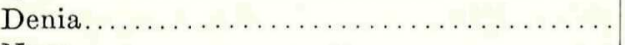 & 54.4 & 7.15 \\
\hline 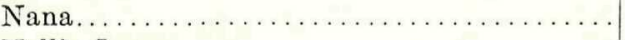 & 62.5 & 7.62 \\
\hline Nellie $\mathrm{Jr} \ldots \ldots \ldots \ldots \ldots \ldots \ldots \ldots \ldots \ldots \ldots \ldots \ldots \ldots$ & 76.4 & 8.21 \\
\hline 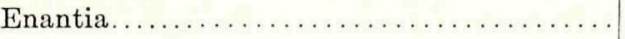 & 55.6 & 6.61 \\
\hline 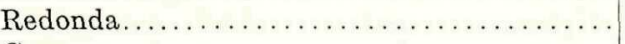 & 50.0 & 5.95 \\
\hline 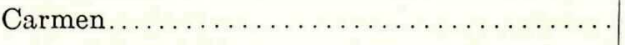 & 63.1 & 8.64 \\
\hline Average $\ldots \ldots \ldots \ldots \ldots \ldots \ldots \ldots \ldots \ldots \ldots \ldots \ldots \ldots$ & 70.2 & 7.18 \\
\hline
\end{tabular}

Group 2: Cows receiving Merker silage

\begin{tabular}{|c|c|c|}
\hline Lupe............................. & 59.2 & 6.04 \\
\hline Luisa $32 \ldots \ldots \ldots \ldots \ldots \ldots \ldots \ldots \ldots \ldots \ldots \ldots \ldots$ & 67.7 & 6.57 \\
\hline Nellie............................ & 80.7 & 7.27 \\
\hline 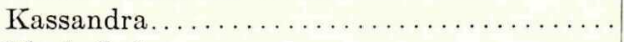 & 66.7 & 7.32 \\
\hline María Luisa.......................... & 60.0 & 6.45 \\
\hline 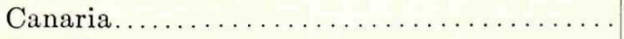 & 79.8 & 7.74 \\
\hline 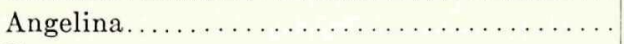 & 62.3 & 6.48 \\
\hline 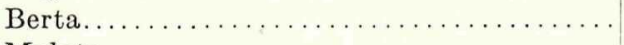 & 59.1 & 7.29 \\
\hline 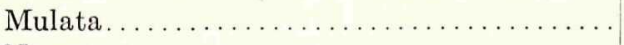 & 60.4 & 8.05 \\
\hline 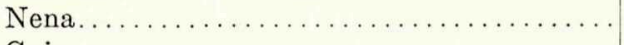 & 60.2 & 7.08 \\
\hline 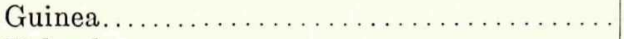 & 67.7 & 7.87 \\
\hline Yolanda .......................... & 49.3 & 5.41 \\
\hline Average.. & 64.4 & 6.96 \\
\hline
\end{tabular}

The analysis of variance of the differences in production between the base and test periods is shown below. The significant mean square for groups indicates a real superiority of the silage. 


$\begin{array}{lccc}\text { Source of variance } & \text { DF } & \text { Mean square } & F \\ \text { Groups } & 1 & 9.50 & 8.96 \\ \text { Within groups } & 22 & 1.06 & \\ & - & & \end{array}$

Difference between groups, $1.26 \pm .42$

The results of this short trial indicate that the mature Merker grass silage was a better forage for lactating cows than the Para grass with which it was compared. The difference might have been greater if the test period had been longer.

The cows on the silage consumed 1.64 pounds of dry matter per 100 pounds of body weight as compared with 2.19 pounds of dry matter per 100 pounds of body weight for the group on soilage. Milk production on the silage was considered satisfactory, particularly since the feeding period was hardly long enough for the animals to become accustomed to the silage; production was maintained better than with Para grass.

\section{Immature Merker Grass Silage Vs. Mature Merker Grass Silage}

A grass field was selected to make the silage for this trial. The immature grass was cut when 60 days old and the mature 34 days later. In this feeding trial two groups of five cows each were used. Direct comparison of the production of the cows during the feeding period was made. Table 4 shows the average daily production of the two groups, while table 5 shows the forage consumption during the experimental periods.

The analysis of variance of the difference in production, as shown below indicates that there was no significant difference between the two silages compared.

$\begin{array}{lccc}\text { Source of variation } & \text { DF } & \text { Mean squares } & \text { F value } \\ \text { Groups } & 1 & 0.3881 & 0.1259 \\ \text { Within groups } & 8 & 3.083 & \end{array}$

There was a highly significant difference between the dry matter consumed by the cows on the mature Merker grass silage and that consumed by the cows on the immature Merker grass silage, (see table 5) as shown in the analysis of variance presented below.

$\begin{array}{lrcl}\text { Source of variation } & D F & \text { Mean squares } & \text { F value } \\ \text { Group } & 1 & 0.1871 & 7.65 \\ \text { Within groups } & 8 & 0.02476 & \end{array}$

\section{Immature Merker Grass Silage Vs. Mature Merker Grass Silage Vs. Mature Merker Grass Soilage}

The silages used in this trial were prepared during September and October 1948. The grass used to prepare them came from the same field which 
TABLE 4.-Milk production per day of cows receiving immature and mature Merker grass silage

\begin{tabular}{|c|c|c|c|}
\hline Cow & Base period & Test period & Difference \\
\hline \multicolumn{4}{|c|}{ Group 1: Cows receiving immature Merker silage } \\
\hline & Pounds & Pounds & Pounds \\
\hline María..... & 13.02 & 14.33 & 1.31 \\
\hline Coamo..................... & 11.70 & 13.42 & 1.72 \\
\hline Soroca....................... & 25.38 & 25.73 & .35 \\
\hline Luisa . . . . . . . & 13.07 & 11.24 & -1.83 \\
\hline Walker Jr...... & 10.36 & 10.20 & -.16 \\
\hline Average...... & 14.70 & 14.98 & -.28 \\
\hline
\end{tabular}

Group 2: Cows receiving mature Merker silage

\begin{tabular}{|c|c|c|c|}
\hline 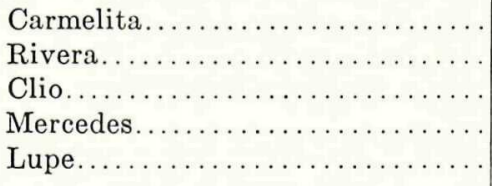 & $\begin{array}{l}16.62 \\
17.51 \\
17.49 \\
18.31 \\
17.72\end{array}$ & $\begin{array}{l}15.33 \\
17.97 \\
20.57 \\
18.69 \\
15.35\end{array}$ & $\begin{array}{r}-1.29 \\
.46 \\
3.08 \\
.38 \\
-2.37\end{array}$ \\
\hline Average............ & 17.53 & 17.58 & .05 \\
\hline
\end{tabular}

TABLE 5.-Forage consumption during test period of cows on immature and mature Merker grass silage

\begin{tabular}{|c|c|c|c|}
\hline Cow & Average per day & $\begin{array}{l}\text { Per } 100 \text { lbs. body } \\
\text { weight }\end{array}$ & $\begin{array}{l}\text { Dry matter per } 100 \\
\text { lbs. body weight }\end{array}$ \\
\hline \multicolumn{4}{|c|}{ Group 1: Cows receiving immature Merker grass silage } \\
\hline & Pounds & Pounds & Pounds \\
\hline María.... & 76.11 & 8.5 & 1.7 \\
\hline Coamo..... & 70.28 & 8.6 & 1.8 \\
\hline Soroca...................... & 75.00 & 8.9 & 1.8 \\
\hline Luisa....................... & 69.30 & 7.6 & 1.6 \\
\hline Walker Jr................... & 75.30 & 6.8 & 1.4 \\
\hline$\ldots \ldots \ldots \ldots \ldots \ldots$ & 73.20 & 8.1 & 1.7 \\
\hline \multicolumn{4}{|c|}{ Group 2: Cows receiving mature Merker silage } \\
\hline Carmelita................... & 54.86 & 6.3 & 1.8 \\
\hline Rivera....... & 56.00 & 6.8 & 1.9 \\
\hline Clio..................... & 70.03 & 7.7 & 2.1 \\
\hline Mercedes.................... & 63.97 & 7.0 & 2.0 \\
\hline Lupe........ & 72.50 & 6.7 & 1.9 \\
\hline 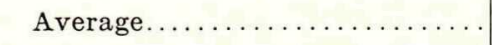 & 63.47 & 6.9 & 1.9 \\
\hline
\end{tabular}


was cut previously for the earlier Merker grass trial. The silage phase of this trial was a repetition of the earlier trial.

Table 6 shows the differences in milk production for the three groups of cows receiving the different roughages.

TABLE 6.-Difference in average daily production of cows receiving immatureand mature Merker grass silage and mature Merker grass

\begin{tabular}{|c|c|c|c|c|c|}
\hline \multicolumn{2}{|c|}{ Immature Merker silage } & \multicolumn{2}{|c|}{ Mature Merker silage } & \multicolumn{2}{|c|}{ Mature Merker grass } \\
\hline Cow & Production & Cow & Production & Cow & Production \\
\hline & Pounds & & Pounds & & Pounds \\
\hline Pipiola.. & 2.81 & Dulcy & 1.87 & Tequila & 6.02 \\
\hline Mercedita... & .74 & Libertad & 4.98 & Laura & 4.93 \\
\hline Nélida...... & 3.12 & Dolly & 2.82 & Inés & 4.31 \\
\hline S. S. $17 \ldots \ldots \ldots \ldots$ & 1.81 & Redonda Jr. & 3.14 & Candy & 4.73 \\
\hline Gloria............ & .92 & Angelina & 1.60 & Geña Jr. & 4.73 \\
\hline Carmelita........ & 2.60 & Nellie & 1.92 & Bola & 1.31 \\
\hline Berta............... & 1.85 & Bonita & .75 & Soroca & 4.45 \\
\hline 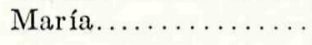 & 1.52 & Dunure Jr. & .25 & Carmen & 1.47 \\
\hline Total. & 11.95 & Total & 16.83 & Total & 31.95 \\
\hline
\end{tabular}

The analysis of variance of the above differences is shown below:

$\begin{array}{lrccc}\begin{array}{l}\text { Source of variance } \\ \text { Total }\end{array} & \text { DF } & \text { SS } & \text { Mean square } & \text { F value } \\ \text { Groups } & 2 & 56.25 & 28.125 & 8.22 \\ \text { Within groups } & 21 & 71.84 & 3.42 & \end{array}$

There was a significant difference in production between the groups. The value for the comparison of the three roughages was as follows: Immature Merker grass silage and mature Merker grass silage 1.93*; immature Merker grass silage and mature Merker grass 3.807**; mature Merker grass silage and mature Merker grass 2.21 .

These values indicate that the immature Merker grass silage was statistically superior to mature Merker grass silage at the 5 percent point. On the other hand the mature Merker silage ranked superior at the 5 percent point to the mature Merker grass fed green. The immature Merker grass silage was superior to the mature grass soilage at the 1 percent level.

Although the results obtained from the silages in this trial were differ ent from those obtained in the earlier one, after pooling the data the difference in production was not significant.

The analysis of variance for the production of cows on immature and mature Merker grass silage (pooled data) is shown below:

$\begin{array}{lrcll}\text { Source of variance } & D F & \text { Mean square } & \text { F value } & \\ \text { Group } & 1 & 6.1753 & 6.1753 & 1.40 \\ \text { Error } & 24 & 105.5876 & 4.40 & \end{array}$


There was no significant difference in the analyses of the constituents of the three roughages studied.

TABLE 7.-Average milk production per day of cows on Para grass silage containing 5-and-10 percent of molasses, and on mature Merker grass fed green during base and test periods

\begin{tabular}{|c|c|c|c|}
\hline Cow & Base period & Test period & Difference \\
\hline \multicolumn{4}{|c|}{ Group 1: Cows on Para grass silage with 5 percent of molasses } \\
\hline & Pounds & Pounds & Pounds \\
\hline Princesa. . & 38.96 & 33.75 & -5.21 \\
\hline Ingrid.... & 18.57 & 13.94 & -4.62 \\
\hline Gacha........... & 14.02 & 9.96 & -4.06 \\
\hline Nena....................... & 13.12 & 10.56 & -2.56 \\
\hline Nellie $\mathrm{Jr} \ldots \ldots \ldots \ldots \ldots \ldots \ldots \ldots$ & 18.75 & 13.01 & -5.74 \\
\hline Esmeralda..................... & 16.06 & 14.25 & -1.81 \\
\hline Average..... & 19.91 & 15.91 & -4.00 \\
\hline
\end{tabular}

Group 2: Cows on Para grass silage with 10 percent of molasses

\begin{tabular}{|c|c|c|c|}
\hline 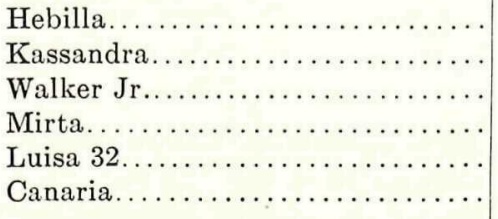 & $\begin{array}{l}13.01 \\
16.68 \\
38.46 \\
18.84 \\
29.72 \\
13.61\end{array}$ & $\begin{array}{r}10.07 \\
12.43 \\
36.06 \\
15.46 \\
26.54 \\
9.41\end{array}$ & $\begin{array}{l}-2.94 \\
-4.26 \\
-2.40 \\
-3.38 \\
-3.18 \\
-4.20\end{array}$ \\
\hline Average...$\cdots \cdots \ldots \ldots \ldots \ldots$ & 21.72 & 18.33 & -3.39 \\
\hline
\end{tabular}

Group 3: Cows on mature Merker grass fed green

\begin{tabular}{|c|c|c|c|}
\hline Carmen...................... & 26.25 & 27.68 & 1.03 \\
\hline Denia................. & 19.27 & 20.09 & .82 \\
\hline Walker................... & 31.52 & 33.17 & 1.65 \\
\hline Lupe........................ & 31.05 & 32.70 & 1.68 \\
\hline Dunure Jr.................... & 42.60 & 45.14 & 2.54 \\
\hline Vera........................... & 13.30 & 15.48 & 2.18 \\
\hline Average. . & 27.40 & 29.04 & 1.65 \\
\hline
\end{tabular}

\section{Para Grass Silage With 5- and 10-Percent Molasses Vs. Mature Merker Grass}

In this trial the production of the cows during the test period on the three roughages was compared with a lactating period prior to the test period equally long in days, called the base period. The three groups of 
animals were groups fed. Table 7 shows the average daily production of the cows during the experimental period as compared to the base period. Observe the marked difference in the reaction of the cows to the three roughages.

Using the difference in the production obtained by comparing the test period with the base period it was found that the difference among the treatments was highly significant as shown below. Merker grass fed green was superior to Para grass silage with 5 or 10 percent of molasses. There was no significant difference in the production of the cows receiving the Para grass silages.

The analysis of variance of the difference in average daily milk production between the base and the test period is shown below:

$\begin{array}{lrcc}\text { Source of variance } & D F & \text { Mean square } & \text { F value } \\ \text { Group } & 2 & 57.725 & 52.35 \\ \text { Within groups } & 15 & 1.102 & \end{array}$

The average dry-matter consumption for the three groups was as follows: Group 1: Para grass silage with 5 percent of molasses, 1.63 pounds of dry matter per 100 pounds of body weight; Group 2: Para grass silage with 10 percent of molasses, 1.88 pounds of dry matter per 100 pounds of body weight; Group 3: Merker grass fed green, 2.01 pounds of dry matter per 100 pounds of body weight.

In spite of the molasses in Para grass silages, these were the poorest in odor, color, etc. The difference in consumption between the Merker grass soilage and the silages was probably because of its greater palatability. All the animals maintained their weight during the experiment.

\section{Mature Merker Grass Silage Vs. Immature Merker Grass}

Approximately 10 percent of molasses was used in the preparation of this silage. The grass fed was in its early-maturing stages containing an average of 82.60 percent of moisture. Table 8 shows the average milk production for the experimental period as compared with a base period.

The analysis of variance shown below for the milk production data indicates that Merker grass fed as silage was statistically superior to immature Merker grass silage under our experimental conditions.

The analysis of variance for milk production is shown below:

$\begin{array}{lrcr}\text { Source of variance } & D F & \text { Mean Square } & \text { F value } \\ \text { Group } & 1 & 12.3963 & 20.67 \\ \text { Within groups } & 12 & .5996 & \end{array}$

The two groups were group-fed and they averaged 1.98 pounds of dry matter per 100 pounds of body weight; this shows that the silage was as palatable for both groups as the green forage. 
TABLE 8.-Average milk production per day of cows on Para grass silage containing 5-and-10 percent of molasses, and on mature Merker grass fed green during base and test periods

\begin{tabular}{|c|c|c|c|}
\hline Cow & Base period & Test period & Difference \\
\hline \multicolumn{4}{|c|}{ Group 1: Cows receiving mature merker grass silage } \\
\hline & Pounds & Pounds & Pounds \\
\hline Princesa. & 27.46 & 28.46 & .80 \\
\hline Ingrid. . . & 12.92 & 13.64 & .72 \\
\hline Gacha. . & 8.97 & 10.24 & 1.27 \\
\hline Nellie Jr....................... & 13.46 & 13.54 & .08 \\
\hline 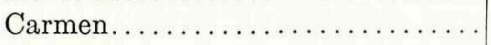 & 18.92 & 19.10 & .18 \\
\hline Hebilla.... & 9.16 & 9.40 & .24 \\
\hline Kassandra... & 12.20 & 11.99 & -.21 \\
\hline Average..... & 14.73 & 15.17 & .44 \\
\hline
\end{tabular}

Group 2: Cows receiving immature Merker grass

\begin{tabular}{|c|c|c|c|}
\hline Denia............. & 14.64 & 13.60 & -1.04 \\
\hline Walker........ & 24.40 & 22.76 & -1.64 \\
\hline Esmeralda.................... & 12.58 & 11.36 & -1.22 \\
\hline 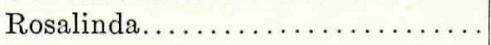 & 6.74 & 5.27 & -1.47 \\
\hline Dunure $\mathrm{Jr} . . . \ldots \ldots \ldots \ldots$ & 30.53 & 30.80 & .27 \\
\hline Canaria.................. & 12.54 & 9.60 & -2.94 \\
\hline 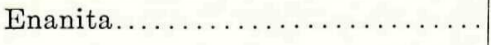 & 6.29 & 5.52 & .77 \\
\hline Average.... & 15.39 & 14.13 & -1.25 \\
\hline
\end{tabular}

TABLE 9.-Average daily production of the cows on Merker-kudzu silage and on mature Merker grass

\begin{tabular}{|c|c|c|c|}
\hline \multicolumn{2}{|c|}{ Merker-kudzu silage } & \multicolumn{2}{|l|}{ Merker grass } \\
\hline Cow & Production & Cow & Production \\
\hline & Pounds & & Pounds \\
\hline María. .......... & 8.90 & Toledo Jr............... & 5.31 \\
\hline Gloria. . & 20.48 & India $\mathrm{Jr} \ldots \ldots \ldots \ldots \ldots$ & 8.16 \\
\hline Lupe............ & 3.12 & Yolanda.......... & 5.19 \\
\hline Rivera........... & 5.87 & Sisa. . . . . . . & 7.76 \\
\hline Gaviota........ & 6.76 & Paloma..... & 7.53 \\
\hline Carmelita.............. & 13.51 & Nellie..... & 14.75 \\
\hline Carmen............... & 6.18 & Dunure Jr............ & 8.44 \\
\hline Berta............... & 4.99 & Rio Piedras Jr.......... & 4.56 \\
\hline Soroca............... & 14.67 & Ida............ & 11.24 \\
\hline Gachita.......... & 9.00 & Cleo......... & 8.88 \\
\hline Aura............. & 8.46 & Lila Jr...... & 4.70 \\
\hline María Luisa. . . . . & 5.60 & Correa............... & 5.69 \\
\hline Total. .............. & 107.44 & 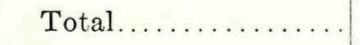 & 90.20 \\
\hline
\end{tabular}




\section{Comparison of Merker-Kudzu Silage and Merker Grass}

The silage was prepared during July 1948. The Merker grass was mature. Merker-kudzu mixture makes a palatable silage and was readily

TABLE 10.-Average daily production and the statistical arrangement for the calculation of the experiment with cows fed mature Merker grass and sugarcane silage

\begin{tabular}{|c|c|c|c|c|c|c|}
\hline \multirow{2}{*}{ Cow } & \multicolumn{6}{|c|}{ Results for experimental periods- } \\
\hline & 1 & 2 & 3 & $1 \times 3$ & $2(2)$ & $D$ \\
\hline \multicolumn{7}{|c|}{ Mature Merker grass } \\
\hline & Pounds & Pounds & Pounds & Pounds & Pounds & Pounds \\
\hline Gachita. & 25.62 & 22.35 & 21.15 & 46.77 & 44.70 & 2.06 \\
\hline Kassandra. & 35.88 & 31.78 & 27.40 & 63.28 & 63.56 & -0.28 \\
\hline Denia.. & 27.15 & 23.94 & 22.37 & 49.52 & 47.88 & 1.64 \\
\hline Nélida. . . . . . . . & 12.26 & 11.31 & 10.07 & 22.33 & 22.62 & -0.29 \\
\hline Mercedes... & 20.31 & 21.27 & 19.15 & 39.46 & 42.54 & -3.08 \\
\hline Luna. . & 13.23 & 13.77 & 13.02 & 26.25 & 27.54 & -1.29 \\
\hline Sum. & & & & & & -1.24 \\
\hline \multicolumn{7}{|c|}{ Sugarcane silage } \\
\hline Sisa. & 25.08 & 14.13 & 15.65 & 40.73 & 28.26 & 12.47 \\
\hline Dolly. . & 19.31 & 14.55 & 16.52 & 35.83 & 29.10 & 6.73 \\
\hline María. . & 36.36 & 29.13 & 32.37 & 68.73 & 58.26 & 10.47 \\
\hline Berta...... & 20.30 & 16.21 & 17.35 & 37.65 & 32.42 & 5.23 \\
\hline Dulcy..... & 17.69 & 14.42 & 17.34 & 35.03 & 28.84 & 6.19 \\
\hline Josefina. . & 14.76 & 10.94 & 13.29 & 28.05 & 21.88 & 6.17 \\
\hline Sum..... & & & & & & 47.26 \\
\hline
\end{tabular}

consumed by the cows. Table 9 shows the average daily production of the cows in both groups.

$\begin{array}{lrccr}\text { Source of variance } & \text { DF } & \text { SS } & \text { Mean square } & \text { F value } \\ \text { Treatments } & 1 & 11.48 & 11.48 & 0.6632 \\ \text { Error } & 22 & 380.87 & 17.31 & \end{array}$

The analysis of variance as shown indicates that there was no significant difference in the production of the cows on Merker-kudzu silage and Merker grass fed green. This was probably because the proportion of kudzu in the mixture was very low making little difference in the nutritive value.

The forage consumption study indicates that the groups of cows on the Merker-kudzu silage consumed 1.61 pounds of dry matter per 100 pounds, as compared with 1.45 pounds of dry matter per 100 pounds of weight for the groups on Merker grass. 
Both groups of cows maintained their body weight throughout the experimental period.

\section{Comparison of Sugarcane Silage Vs. Merker Grass}

The silage used in this feeding trial was prepared during the early days of September 1949. The sugarcane used was from 4 to 5 months old, in the usual way, chopped through a silage chopper, and blown into two tower silos. The average moisture content was 79.70 percent.

The mature Merker grass used came from our fields with an average of 71.28 percent moisture content. The whole sugarcane plant makes a rather palatable silage; farmers should take the advantage of this and the heavy tonnage it produces. The high carbohydrate content serves as a good preservative. Table 10 gives the results.

The statistical analysis of the milk production of the different groups indicated that there was a highly significant difference in the production in favor of the group receiving the immature sugarcane silage.

The statistical analysis of the dry-matter consumption per 100 pounds of body weight indicates that the cows on the immature sugarcane silage consumed less (1.49 pounds) than the cows on mature Merker grass (1.98 pounds).

The cows in both groups maintained their body weight throughout the experimental periods.

The results obtained indicate that immature sugarcane silage is a good source of roughage for dairy cows.

\section{SUMMARY AND CONCLUSIONS}

A series of feeding trials comparing mature Merker grass silage vs. mature Para grass soilage; immature Merker grass silage vs. mature Merker grass silage; immature Merker grass silage vs. mature Merker grass silage vs. mature Merker grass soilage; mature Para grass silage with 5 or 10 percent of molasses vs. mature Merker grass; mature Merker grass silage vs. immature Merker grass soilage; mature Merker-kudzu grass silage vs. mature Merker grass; and immature sugarcane silage vs. mature Merker grass soilage, were conducted during the period between January 1947 and January 1950. The purpose was to determine the value of the above roughages as silage.

A summary of the proximate analyses of the roughages and silages used is presented.

The following are the conclusions obtained from these trials.

1. Mature Merker grass silage was a more satisfactory source of forage for lactating cows than mature Para grass soilage.

2. The cows on the mature Para grass silage consumed as much as 1.64 
pounds of dry matter per 100 pounds of body weight as compared to 2.19 pounds of dry matter per 100 pounds of body weight of the mature Merker grass soilage.

3. There was no significant difference in the production of cows receiving immature Merker grass silage and that of the cows receiving mature Merker grass silage. When the experiment was repeated there was a difference in production in favor of the immature grass silage but, after pooling the data, the difference between the two silages was not significant.

4. There was a highly significant difference between the dry matter consumed by the cows on mature Merker grass silage with 1.92 pounds per 100 pounds of body weight as compared with 1.651 pounds per 100 pounds of body weight for the immature Merker grass silage.

5. There was a highly significant difference between immature Merker grass silage and mature Merker grass soilage and a significant difference between mature Merker grass silage and mature Merker grass soilage.

6. There were no significant differences among the analyses of the constituents of the above three roughages.

7. There was a highly significant difference in the production of the cows on mature Merker grass soilage as compared to that of the cows on mature Para grass silage with 5 or 10 percent of molasses added.

8. There was no significant difference between the production of the cows on Para grass silage with 5 or 10 percent of molasses.

9. The dry-matter consumption for the cows on Para grass silage with 5 percent of molasses was 1.63 pounds per 100 pounds of body weight compared to 1.88 pounds per 100 pounds of body weight for the cows on Para grass silage with 10 percent of molasses, and 2.01 pounds per 100 pounds of body weight for the cows on mature Merker grass fed green.

10. The difference in milk production for the cows on mature Merker grass silage was highly significant when compared to that of the immature Merker soilage group.

11. Both groups consumed an average of 1.98 pounds of dry matter per 100 pounds of body weight.

12. There was no significant difference in milk production of the cows on Merker-kudzu silage and Merker grass fed green.

13. The cows on Merker-kudzu silage consumed an average of 1.61 pounds of dry matter per 100 pounds of body weight consumed by the group of cows on Merker grass.

14. There was a highly significant difference in the production of the cows receiving immature sugarcane silage as compared to that of the cows receiving mature Merker grass.

15. Cows on immature sugarcane silage consumed less dry matter (1.49 pounds) per 100 pounds of body weight than the cows on mature Merker 
grass which consumed 1.98 pounds of dry matter per 100 pounds of body weight.

16. Merker grass and young sugarcane silages are good sources of roughage for dairy cows. They are still more important during prolonged dry periods when pastures are not available and also when good soilage grasses cannot be obtained.

\section{RESUMEN Y CONCLUSIONES}

Este estudio incluye los datos de una serie de experimentos sobre la alimentación del ganado lechero, obtenidos de los siguientes tratamientos:

1. Ensilaje de yerba Merker madura vs. yerba Pará cortada y madura.

2. Ensilaje de yerba nueva vs. ensilaje de yerba Merker madura vs. yerba Merker cortada madura.

3. Ensilaje de yerba Pará con 5 ó 10 por ciento de miel vs. yerba Merker cortada madura.

4. Ensilaje de yerba Merker madura vs. yerba Merker cortada nueva.

5. Ensilaje de la asociación Merker-kudzú vs. yerba Merker cortada madura.

6. Ensilaje de caña de azúcar nueva vs. yerba Merker cortada madura.

Todos los experimentos se llevaron a cabo durante el período comprendido entre enero, 1947 y enero, 1950.

Los resultados y conclusiones se compendian como sigue:

1. Para las vacas en lactancia, el ensilaje de yerba Merker madura fué mejor fuente de forraje que la yerba Pará cortada madura.

2. Las vacas, en el tratamiento con ensilaje de yerba Pará madura, consumieron hasta 1.64 libras de materia seca por cada 100 libras de peso, y las del tratamiento con la yerba Merker cortada madura 2.19.

3. No hubo diferencia significativa en la producción de leche de las vacas comprendidas en el tratamiento con ensilaje de Merker nueva. Cuando se repitió el experimento, hubo alguna diferencia a favor del ensilaje de Merker nueva, pero después de estudiar los datos en conjunto, esta diferencia entre ambos tratamientos resultó insignificante.

4. Hubo una diferencia altamente significativa. Con relación a la materia seca consumida por las vacas, a razón de 100 libras de peso, entre los tratamientos con ensilaje de Merker madura y el ensilaje con Merker nueva que alcanzó a 1.92 y 1.65 libras, respectivamente.

5. Hubo una diferencia altamente significativa entre el tratamiento con el ensilaje de Merker nueva y el de Merker cortada nueva y sólo significativa entre el de ensilaje de Merker madura y la Merker cortada madura.

6. No hubo diferencias significativas entre los elementos nutritivos de los forrajes usados.

7. Hubo una diferencia altamente significativa en la producción de leche 
de las vacas comprendidas en el tratamiento con la yerba Merker cortada madura, al compararse con las que consumieron ensilaje de la yerba Pará, al cual, se le añadió 5 ó 10 por ciento de miel.

8. No hubo diferencia significativa entre la producción de leche de las vacas en el tratamiento con el ensilaje de yerba Pará, cuando se le añadió 5 ó 10 por ciento de miel.

9. El consumo de materia seca por las vacas, en el tratamiento con ensilaje de Pará al cual se le añadió el 5 por ciento de miel, fué 1.63 libras por 100 libras de peso; de 1.88 libras en el tratamiento con ensilaje de yerba Pará, con el 10 por ciento de miel; y de 2.01 libras para las vacas en el tratamiento con yerba Merker cortada madura.

10. La diferencia en la producción de leche de las vacas en el tratamiento con ensilaje de yerba Merker cortada madura, fué altamente significativa cuando se comparó con el del tratamiento con yerba Merker cortada nueva.

11. En ambos casos anteriores, las vacas consumieron, en promedio, 1.97 libras de materia seca por cada 100 libras de peso.

12. No hubo diferencia significativa en la producción de leche de las vacas, entre el tratamiento con el ensilaje de la asociación Merker-kudzú y el tratamiento de yerba Merker cortada madura.

13. Las vacas en el tratamiento con el ensilaje Merker-kudzú, consumieron en promedio, 1.62 libras más de materia seca por 100 libras de peso, que las vacas en el tratamiento con yerba Merker cortada madura.

14. Hubo una diferencia altamente significativa en la producción de leche de las vacas en el tratamiento con ensilaje de caña de azúcar nueva, cuando se comparó con las del tratamiento con Merker cortada madura.

15. Las vacas en el tratamiento con ensilaje de caña de azúcar nueva, consumieron más materia seca (1.49 libras) por 100 libras de peso que las vacas en el tratamiento con yerba Merker cortada madura, las cuales consumieron 1.97 libras.

16. Los ensilajes de yerba Merker y los de caña cortada nueva son excelentes medios de proveer forraje à las vacas lecheras. Resultan aún más esenciales para la alimentación del ganado durante las temporadas de prolongadas sequías y también cuando es difícil poder conseguir buenas yerbas para corte.

\section{LITERATURE CITED}

1. U. S. D. A. Farmer's Bul. 321903.

2. May, D. W., Dairying in Puerto Rico, Puerto Rico Agricultural Experiment Station, Mayaguez, P. R., Bul. 29 12-13, 1922.

3. Rivera Brenes, L., Marchán, F., and Del Toro, E., Studies on silage in Puerto Rico I, Methods of ensiling and resulting quality of Merker, cane tops and Para grass silages, Jour. Agr. Univ. P. R. 31 (2) 168-79 1947. 